\title{
Historic Flooding in Northern Georgia, September 16-22, 2009
}

A primary mission of the U.S. Geological Survey (USGS) is the measurement and documentation of the magnitude and extent of hydrologic hazards, such as floods, droughts, and hurricane storm surge. USGS personnel were deployed to document historic, widespread flooding that occurred throughout the Atlanta metropolitan area and northwestern Georgia in the early fall of 2009. The floods were created by prolonged rainfall that occurred during September 16-22, 2009, with an especially intense period of rainfall during the late evening of September 20. The National Weather Service (NWS) reported that the southeastern United States had above-normal precipitation from August into early September, resulting in saturated soil conditions making the region extremely flood prone. Precipitation totals were the sixth highest on record for the month of September for the region (National Weather Service, 2010).

Monetary losses reported from this flood were nearly $\$ 220$ million in flood-damage claims, with 17 counties declared Federal disaster areas. Eleven fatalities were attributed to this flood, with many of them occurring during early morning hours when drivers attempted to cross flooded roads. Significant damage to hundreds of roads and bridges across the region also severely impacted traffic conditions for months after the event (National Weather Service, 2010).

The September 2009 flooding brought the highest levels ever recorded

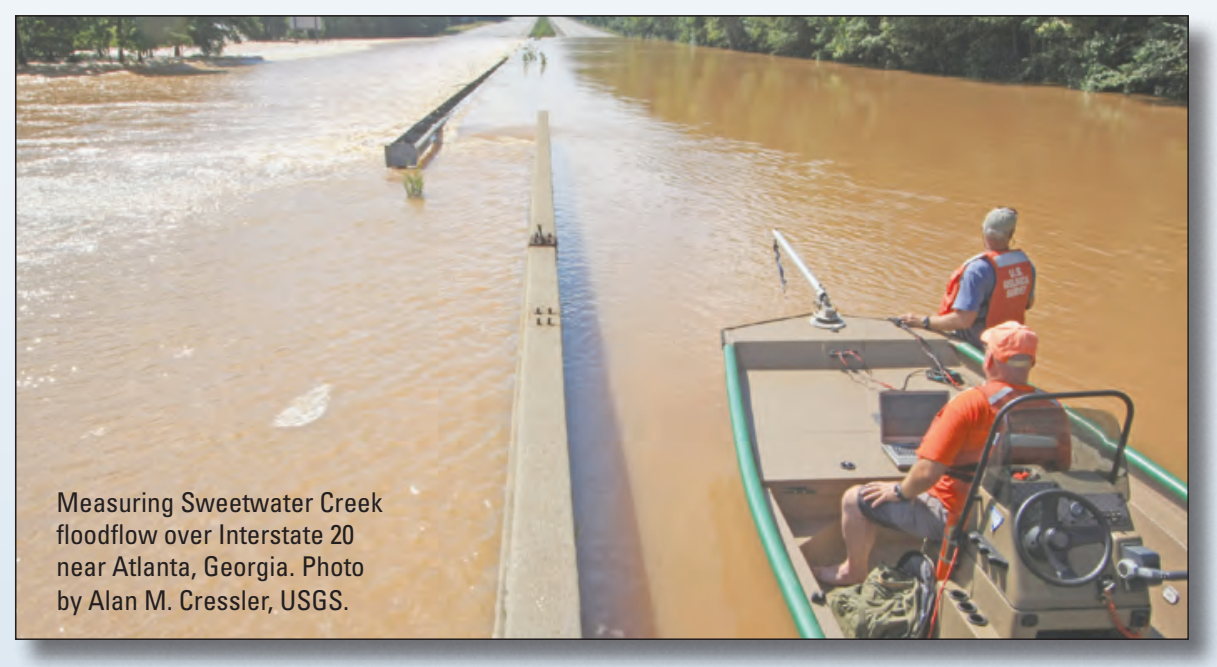

at many USGS streamgages across the region. Particularly hard hit was the Chattahoochee River Basin, west of Metropolitan Atlanta. At USGS gaging station 02336000 on the Chattahoochee River at Atlanta, Georgia, a peak flow of 40,900 cubic feet per second $\left(\mathrm{ft}^{3} / \mathrm{s}\right)$ and a peak stage of 28.12 feet (ft) were recorded on September 21. This was the highest stage in 81 years of continuous record at the gage. The September 22 peak flow represented between a 1 - and 0.5 -percent annual exceedance probability (100- to 200-year) flood. Station 02337000 on Sweetwater Creek near Austell, Georgia, recorded a stage of $30.82 \mathrm{ft}$ with a peak flow of $31,500 \mathrm{ft}^{3} / \mathrm{s}$, which resulted in an exceedance probability much greater than the 0.2 -percent (500-year) flood level and caused the closure of Interstate 20 for more than a day. Hardest hit was the Dog River Basin in Douglas County, where floodwaters rose $12 \mathrm{ft}$ above USGS streamgage 02337410. The Dog River crested at a stage of $33.83 \mathrm{ft}$ with a streamflow estimate of $59,900 \mathrm{ft}^{3} / \mathrm{s}$, which was almost six times the 100-year flood. Upstream from Atlanta, Lake Sidney Lanier rose almost $4 \mathrm{ft}$ in a 48 -hour period following the storm and is credited for preventing record flood levels in Atlanta (James Hathorn, U.S. Army Corps of Engineers, oral commun., November 6, 2009).

Significant flooding occurred in the headwaters of the Altamaha River Basin to the east of Atlanta. At USGS station 02207120 on the Yellow River at GA 124, near Lithonia, Georgia, the highest ever peak stage determined from surveys was $27.47 \mathrm{ft}$ on September 22, with a peak flow of $16,500 \mathrm{ft}^{3} / \mathrm{s}$.
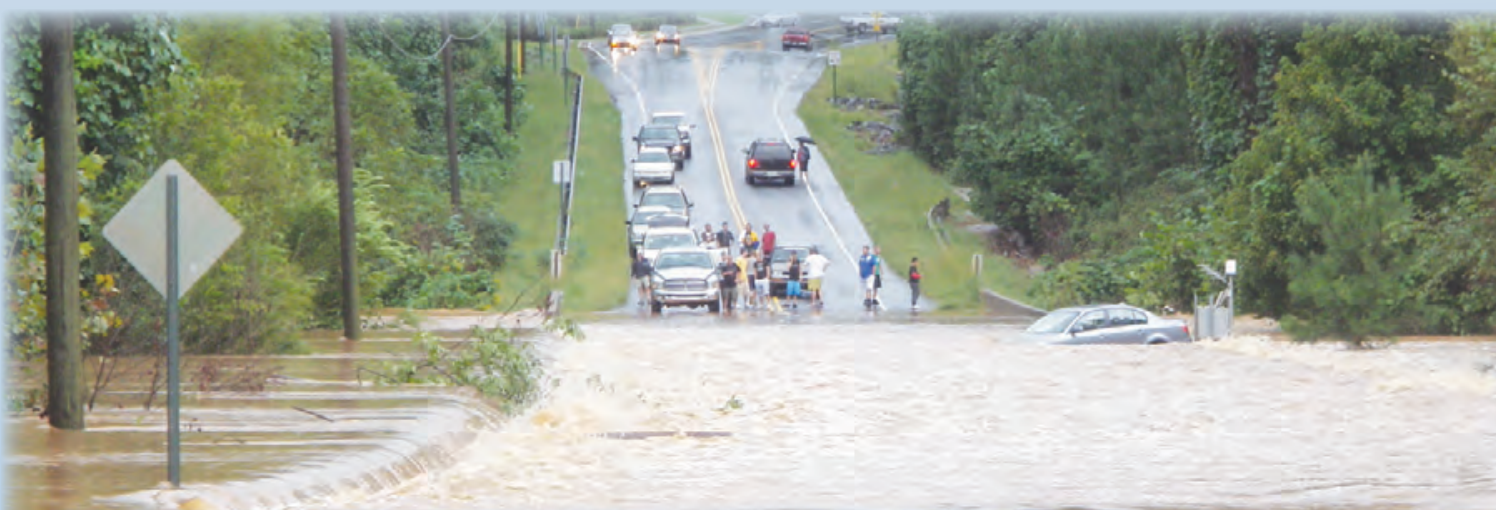

Water flowing over the road from Allatoona Creek at Stilesboro Road near Acworth, Cobb County, Georgia, September 21, 2009. Photo by Andrew E. Knaak, USGS. 

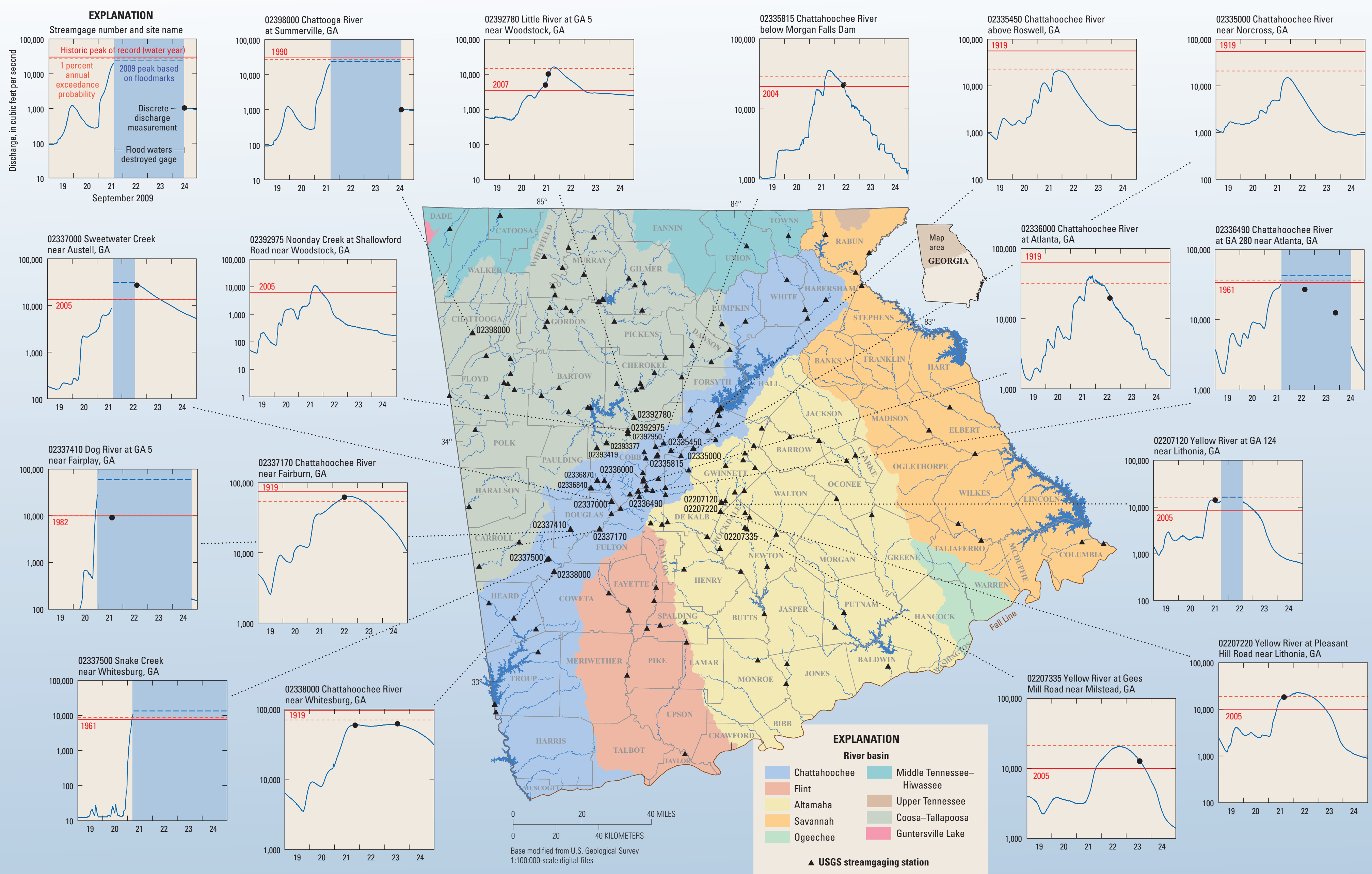

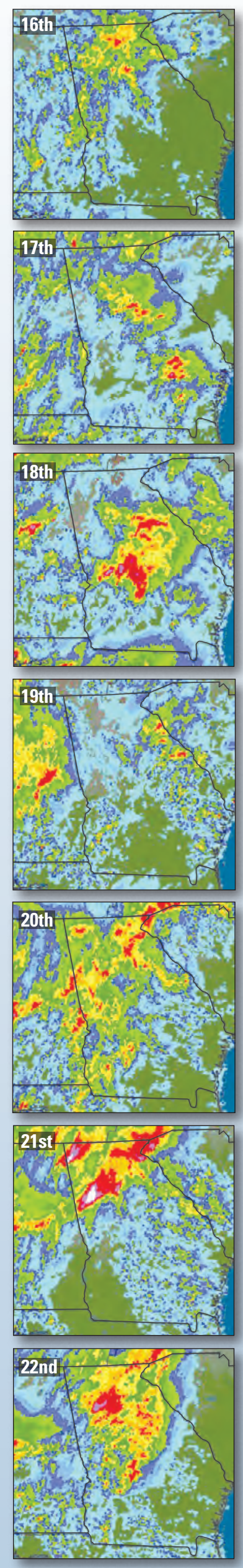

0233684

02336870

02337000

02337170

02337410

02338000

02392780

02392950

02392975

02393377

02393419

02398000
02337500

The Coosa and Tennessee River Basins also were flooded in many locations. The USGS streamgages on Allatoona, Noonday, and Butler Creeks - all tributaries to Allatoona Lakerecorded peak flows with magnitudes far greater than 0.2-percent (500-year) floods. Although these flows caused Allatoona Lake to rise to more than $13 \mathrm{ft}$ above the full-pool level, the dam still saved ral commun., November 6, 2009).

During this historic flood, more than USGS streamgages throughout north Georgia corded flows above the highest ever measured,

Daily precipitation images for September 2009 from the NWS $S$ raingages provide ground verification and provides estimates of rainfall between the raingages to Recorded flooding in September 2009 at selected USGS continuous-monitoring streamgages in northern Georgia.

\begin{tabular}{|c|c|c|c|c|c|}
\hline $\begin{array}{l}\text { Station } \\
\text { identi- } \\
\text { fication }\end{array}$ & Station name & $\begin{array}{c}\text { Date of } \\
\text { peak } \\
\text { (September } \\
\text { 2009) } \\
\end{array}$ & $\begin{array}{c}\text { Peak } \\
\text { flow } \\
\text { (cubic feet } \\
\text { per second) }\end{array}$ & $\begin{array}{c}\text { Peak } \\
\text { gage } \\
\text { height }\end{array}$ & $\begin{array}{c}\text { Annual } \\
\text { exceedance } \\
\text { probability } \\
\text { (percent) }\end{array}$ \\
\hline 02207120 & Yellow River at GA 124, near Lithonia, GA & 22 & 16,500 & 27.47 & 1 to 0.5 \\
\hline 02207220 & $\begin{array}{l}\text { Yellow River at Pleasant Hill Road, } \\
\text { near Lithonia, GA }\end{array}$ & 22 & 22,900 & 25.54 & 0.5 to 0.2 \\
\hline 02207335 & $\begin{array}{l}\text { Yellow River at Gees Mill Road, } \\
\text { near Milstead, GA }\end{array}$ & 22 & 20,800 & 22.54 & 2 to 1 \\
\hline 02335000 & Chattahoochee River near Norcross, GA & 21 & 14,900 & 14.51 & Regulated \\
\hline 02335450 & Chattahoochee River above Roswell, GA & 21 & 21,100 & 11.96 & Regulated \\
\hline 02335815 & $\begin{array}{l}\text { Chattahoochee River below } \\
\text { Morgan Falls Dam, GA }\end{array}$ & 21 & 35,500 & 827.01 & Regulated \\
\hline 02336000 & Chattahoochee River at Atlanta, GA & 21 & 40,900 & 28.12 & Regulated \\
\hline 02336490 & $\begin{array}{l}\text { Chattahoochee River at GA 280, } \\
\text { near Atlanta, GA }\end{array}$ & 21 & 42,300 & 35.98 & Regulated \\
\hline 02336840 & $\begin{array}{l}\text { Sweetwater Creek at Brownsville Road, } \\
\text { Powder Springs, GA }\end{array}$ & 21 & 30,000 & 31.40 & Exceeded 0.2 \\
\hline 02336870 & Powder Springs Creek near Powder Springs, GA & 21 & 8,940 & 19.91 & Exceeded 0.2 \\
\hline 02337000 & Sweetwater Creek near Austell, GA & 22 & 31,500 & 30.82 & Exceeded 0.2 \\
\hline 02337170 & Chattahoochee River near Fairburn, GA & 22 & 63,900 & 30.65 & 1 to 0.5 \\
\hline 02337410 & Dog River at GA 5, near Fairplay, GA & 21 & 59,900 & 33.83 & Exceeded 0.2 \\
\hline 02337500 & Snake Creek near Whitesburg, GA & 21 & 13,500 & 19.42 & Exceeded 0.2 \\
\hline 02338000 & Chattahoochee River near Whitesburg, GA & 23 & 60,600 & 29.74 & Regulated \\
\hline 02392780 & Little River at GA 5, near Woodstock, GA & 21 & 16,100 & 20.80 & 1 to 0.5 \\
\hline 02392950 & $\begin{array}{l}\text { Noonday Creek at Hawkins Store Rd, } \\
\text { near Woodstock, GA }\end{array}$ & 21 & 11,900 & 17.28 & Exceeded 0.2 \\
\hline 02392975 & $\begin{array}{l}\text { Noonday Creek at Shallowford Road, } \\
\text { near Woodstock, GA }\end{array}$ & 21 & 11,400 & 19.66 & Exceeded 0.2 \\
\hline 02393377 & $\begin{array}{l}\text { Butler Creek at Mack Dobbs Road, } \\
\text { near Kennesaw, GA }\end{array}$ & 21 & 6,760 & 14.27 & Exceeded 0.2 \\
\hline 02393419 & $\begin{array}{l}\text { Allatoona Creek at Stilesboro Rd, } \\
\text { near Acworth, GA }\end{array}$ & 21 & 16,600 & 23.90 & Exceeded 0.2 \\
\hline 02398000 & Chattooga River at Summerville, GA & 21 & 23,500 & 21.19 & 2 \\
\hline
\end{tabular}

operation by floodwaters. USGS field personnel performed flood measurements to extend streamforecasts. All 20 streamgages were restored to operational status within 5 days, however.

Lessons learned from this flood include the river information by Federal agencies with floodthreatened communities. Communicating the flood threat in an easy, accessible manner would have helped emergency managers and the public greatly during this flood. In response, the USGS developed WaterAlert (http://water.usgs.gov/wateralert) to send notifications of flood events by way of text and e-mail. Also in development are real-time flood-inundation maps to give the hydrograph spatial context by way of a map-based product.

\section{References}

National Weather Service, 2009, Advanced Hydrologic Prediction Service-Precipitation: U.S. Department of Commerce, National Oceanic and Atmospheric Administration, accessed in January 2010 at http://water.weather.gov/precip/.

National Weather Service, 2010, Service AssessmentsSoutheast United States Floods, September 18-23, 2009: Silver Spring, MD, U.S. Department of Commerce, National Oceanic and Atmospheric Administration, Office of Climate, Water, and Weather Services, accessed in May 2010 at http://www.weather.gov/os/assessments/pdfs/se floods 10.pdf . flow ratings that allowed for more accurate NWS need for more effective communication of the latest 